\title{
Aggressiveness and Perennation of Isolates of Cochliobolus heterostrophus from North Carolina
}

\author{
M. L. Carson, Research Plant Pathologist and Associate Professor, USDA-ARS, Department of Plant Pathology, \\ North Carolina State University, Raleigh 27695-7616
}

\begin{abstract}
Carson, M. L. 1998. Aggressiveness and perennation of isolates of Cochliobolus heterostrophus from North Carolina. Plant Dis. 82:1043-1047.

Selection occurring during the saprophytic or overwintering phase of the life cycle of Cochliobolus heterostrophus, the causal agent of southern leaf blight of maize, may be a factor in the persistence of apparently less aggressive isolates in the pathogen population. The relative aggressiveness and ability to perennate of 22 isolates of $C$. heterostrophus from North Carolina was measured in series of experiments. Significant differences in aggressiveness and percent perennation (overwintering survival) were observed. There was a weak but often significant negative correlation between the ability of isolates to persist on the soil surface and their aggressiveness. The ability of race $\mathrm{O}$ isolates to sporulate on senescent corn leaf discs was positively correlated with their aggressiveness. Selection against increased aggressiveness during overwintering does not appear sufficient by itself to counter selection for increased aggressiveness occurring during the pathogen's pathogenic phase.
\end{abstract}

Southern leaf blight (SLB) of maize, caused by the ascomycete Cochliobolus heterostrophus (Drechs.) Drechs. (anamorph = Bipolaris maydis (Nisikado) Shoemaker; synonym $=$ Helminthosporium maydis Nisikado), is a serious disease of maize throughout the world where maize is grown under warm, humid conditions (21,26). Three races of $C$. heterostrophus have been described $(8,25,32)$. Race $\mathrm{O}$, considered the most common race, is the indigenous race throughout most areas where SLB occurs. Race T, the cause of the 1970 SLB epidemic in North America, is specifically virulent on Texas male-sterile cytoplasm (cmsT) maize due to its ability to produce a polyketide toxin ( $\mathrm{T}$ toxin) to which cmsT maize is sensitive $(14,15)$. After the use of cmsT maize was discontinued following the 1970 epidemic, the frequency of race $\mathrm{T}$ in North America has declined to a very low level. Apparently race $T$ is less fit than race $O$ $(9,11,12,22,23)$. Race $\mathrm{C}$ of $C$. heterostrophus, specifically virulent on $\mathrm{C}$ male-sterile cytoplasm (cmsC) maize, has been reported from China, but is not known to occur elsewhere (32).

Estimates of yield losses due to SLB vary widely, depending upon the race and

Corresponding author: M. L. Carson
E-mail: marty_carson@ @csu.edu

Accepted for publication 11 June 1998.

Publication no. D-1998-0720-04R

This article is in the public domain and not copyrightable. It may be freely reprinted with customary crediting of the source. The American Phytopathological Society, 1998. environment, and can be quite substantial. During the 1970 SLB epidemic, total crop failures due to race $\mathrm{T}$ were reported in the southern United States, while the entire U.S. maize crop in 1970 was reduced by an estimated $15 \%$ by SLB (30). Losses of up to $40 \%$ or more have been demonstrated in inoculated yield loss trials with race $\mathrm{O}$ $(2,4,31)$.

Resistance has been the primary means of SLB control. Resistance to race $T$ is achieved by avoiding use of cms-T hybrids. Resistance to race $\mathrm{O}$ may be inherited in as simple a manner as one $(\mathrm{rhm}, 24)$ or a few recessive nuclear genes $(3,7,27)$, or many genes acting in a mostly additive manner $(1,16,17,19)$. Although virulence to these nuclear genes has not been observed in nature, Kolmer and Leonard (10) were able to increase the aggressiveness of $C$. heterostrophus race $\mathrm{O}$ to a partially resistant maize inbred line through recurrent selection. Their selection increased not only the level of general aggressiveness of C. heterostrophus to all maize inbreds tested, but also increased specific virulence to the partially resistant inbred line on which the recurrent selection was practiced. They speculated that the reason or reasons such selection has not been observed in nature may be due to the rare occurrence of sexual reproduction in $C$. heterostrophus, the low heritability of virulence, and the constantly changing genetic makeup of maize hybrids being grown. Variation in general virulence or aggressiveness is common among field isolates of $C$ heterostrophus race $\mathrm{O}$ in North America (10). Some isolates are less parasitically fit than others, and yet they persist in the population. One mechanism by which pathogens with reduced parasitic fitness may persist is by increased competence during nonparasitic phases of the life cycle. Perennation or overwintering is one such phase (13). The object of this research was to measure variation in the parasitic fitness of field isolates of $C$. heterostophus and to determine its relationship, if any, to their ability to perennate or overwinter under field conditions in North Carolina.

\section{MATERIALS AND METHODS}

Isolates. A sample of 22 isolates of $C$. heterostrophus, collected from maize fields across North Carolina over several years and representing both mating types and races $(\mathrm{O}$ and $\mathrm{T})$, were used in all experiments in this study (Table 1). Isolates were maintained in $15 \%$ glycerol at $-80^{\circ} \mathrm{C}$ and cultured on either $10 \mathrm{~g}$ potato dextrose agar (PDA) with $10 \mathrm{~g} / \mathrm{l}$ glucose or corn leaf agar (CLA; 10).

Greenhouse test of aggressiveness. The 22 isolates were cultured as described above. Conidial suspensions were prepared by washing conidia from the surface of 10to 14-day-old cultures with tap water, filtering the resulting suspension through a double layer of cheesecloth, and determining the conidial concentration with the aid of a hemacytometer. The final concentration was adjusted so that approximately 50 conidia were applied in each $10-\mu$ drop of inoculum applied to leaves. The experiment consisted of a randomized complete block design with three replications of the 22 isolates. The experiment was repeated once. Experimental units consisted of single $15-\mathrm{cm}$-diameter pots planted with four seeds of Pioneer hybrid 3184 in a sterile soilless potting mix (Metromix, Scott's, Inc., Marysville, OH). After emergence, plants were thinned to two plants per pot. Five $10-\mu$ droplets of inoculum were applied to the third or fourth leaf of 3-weekold plants and allowed to air dry prior to being placed overnight in a mist chamber. Plants were returned to the greenhouse bench for 4 days, after which the length of the lesions resulting from each droplet was measured and the mean lesion length on plants in each pot was recorded. Data from the two repetitions of the experiment were combined and analyzed by ANOVA.

Field tests of isolate aggressiveness. Field tests of isolate aggressiveness were conducted over three seasons at the Tidewater Research Station located at Plymouth, North Carolina. Plots were estab- 
lished in 3.25-ha fields that had been machine planted in late April each year with the SLB-susceptible commercial maize hybrid Pioneer brand 3184 (1990 and 1991) or Pioneer brand 3162 (1992). Fields were planted at a plant population of 57,000 plants/ha in rows spaced $0.97 \mathrm{~m}$ apart. Individual plots consisted of single rows $5 \mathrm{~m}$ long and plots were separated from other plots by at least $6 \mathrm{~m}$ in all directions. The experiments were arranged as randomized complete blocks with four replications of each treatment (isolate). Inoculum of each isolate was prepared by soaking sorghum grain overnight in water, draining off excess water, dispensing the soaked grain into 1-liter flasks, autoclaving for $1 \mathrm{~h}$, and inoculating the cooled flasks with a spore suspension of the isolates. The sorghum grain cultures were grown for 2 to 3 weeks at room temperature and then stored at $4^{\circ} \mathrm{C}$ until used. Plots were inoculated at the 4- to 6-leaf growth stage by placing approximately 20 to 30 kernels of the sorghum grain inoculum into the leaf whorls. The length of five random SLB lesions was measured beginning 7 days after inoculation each year. Individual lesions were marked with a waterproof marking pen and were measured on each subsequent measuring date. Lesion lengths were measured every two days for a total of four times in 1990, every three days for a total of five times in 1991, and two times 14 days apart in 1992. Percent SLB severity (\% leaf area affected) was visually assessed on whole plots at the boot (tassel still wrapped in the uppermost leaf), mid- silk, mid-milk, early dent, and 1 week prior to physiological-maturity stages. The area under the disease progress curve (AUDPC) also was calculated based on percent SLB severity ratings (34).

Measurement of perennation. Samples of diseased leaf tissue were harvested from each of the Plymouth plots at the early milk stage of development each year, before any interplot spread of isolates between plots was apparent. Samples were air dried at room temperature in mesh bags, and stored in a cool $\left(15^{\circ} \mathrm{C}\right)$, lowhumidity (relative humidity $<25 \%$ ) room until use. In December of each year, 5-g subsamples were taken from each of the Plymouth tissue samples and placed in foot-sized nylon stockings. Subsamples from each plot also were placed in nylon mesh laundry bags and placed outside to be exposed to ambient conditions from December through March each winter. In the winter of 1990 to 1991, samples were placed on the soil surface at the Reedy Creek Research facility in Raleigh. In the winters of 1991 to 1992 and 1992 to 1993 , samples were overwintered on the soil surface as described above and also approximately $75 \mathrm{~cm}$ above the ground by suspending bags on a wire. At the end of the overwintering or perennation period (end of March), the samples were again air-dried and stored indoors as described above until assayed.

Sporulation assay. Plot samples that had been stored indoors and subsamples that had overwintered outdoors as described above were placed in separate moist chambers consisting of 19 by 15 by 3 $\mathrm{cm}$ sealed plastic storage boxes lined with moistened paper toweling. After 3 days, samples were washed with $50 \mathrm{ml}$ tap water and the resulting suspension examined directly for samples overwintered indoors. For samples overwintered outdoors, the 50-ml suspension was pelleted using a tabletop centrifuge and the resulting pellet resuspended in $2 \mathrm{ml}$ water. The concentration of conidia of $C$. heterostrophus in the suspensions was determined with the aid of a hemacytometer and the total numbers of conidia produced on the samples estimated.

Lesion assay. The relative overwintering of the different isolates also was estimated using a lesion assay on a susceptible hybrid (Pioneer 3184) in field trials at the Genetics Garden, Raleigh, North Carolina. Plots of the susceptible hybrid consisted of single rows, $6.1 \mathrm{~m}$ long and spaced $1 \mathrm{~m}$ apart, with a total of 20 plants in each plot. Assay plots were planted in late April each year. An individual plant in each plot was inoculated with either $50 \mathrm{mg}$ of ground sample that had overwintered indoors or overwintered outside (on the soil surface only in 1991; both on the soil surface and above ground in 1992 and 1993). Plants were inoculated at the 6- to 8-leaf stage by placing the ground samples in the leaf whorl, and the number of lesions resulting were counted 10 days later.

Data analysis. The percent overwintering of isolates was estimated from the sporulation and lesion assays by dividing the number of conidia (sporulation assay)

Table 1. Mean aggressiveness of 22 isolates of Cochliobolus heterostrophus as measured by lesion length, lesion expansion rate (LER), \% southern leaf blight (SLB) disease severity at the mid-silk and early dent stages of host development, and areas under the disease progress curve (AUDPC). Field data are the means over three years (four replications per year) from experiments conducted at the Tidewater Research Station, Plymouth, North Carolina.

\begin{tabular}{|c|c|c|c|c|c|c|c|c|c|c|}
\hline \multirow[b]{2}{*}{ Isolate } & \multirow[b]{2}{*}{ Race } & \multirow[b]{2}{*}{ MAT $^{\mathbf{a}}$} & \multirow[b]{2}{*}{ County $^{b}$} & \multirow[b]{2}{*}{ Year } & \multicolumn{2}{|c|}{ Lesion length (mm) } & \multirow[b]{2}{*}{ LER (mm/day) } & \multicolumn{2}{|c|}{$\%$ SLB } & \multirow[b]{2}{*}{ AUDPC } \\
\hline & & & & & Greenhouse $^{c}$ & Field & & Mid-silk & Early dent & \\
\hline NI112 & $\mathrm{T}$ & $1-1$ & Davidson & 1971 & 1.5 & 1.0 & 0.02 & 0.6 & 3.6 & 776 \\
\hline NI108 & $\mathrm{T}$ & $1-1$ & Currituck & 1971 & 3.4 & 1.7 & 0.07 & 1.2 & 5.7 & 808 \\
\hline NI56 & $\mathrm{O}$ & $1-1$ & Craven & 1971 & 4.0 & 1.5 & 0.04 & 0.7 & 6.1 & 819 \\
\hline $1-1 \mathrm{Bm}$ & $\mathrm{O}$ & $1-1$ & Wilkes & 1985 & 4.5 & 2.8 & 0.14 & 1.5 & 7.6 & 895 \\
\hline NI109b & $\mathrm{T}$ & $1-1$ & Currituck & 1971 & 4.7 & 2.0 & 0.07 & 1.3 & 10.8 & 972 \\
\hline $8-53 \mathrm{Bm}$ & $\mathrm{O}$ & $1-2$ & Wake & 1985 & 6.8 & 3.6 & 0.18 & 4.5 & 21.9 & 1090 \\
\hline 9-39Bm & $\mathrm{O}$ & $1-2$ & McDowell & 1985 & 7.0 & 4.5 & 0.21 & 16.4 & 22.8 & 1150 \\
\hline $\mathrm{Hm} 28$ & $\mathrm{O}$ & $1-2$ & Johnston & 1969 & 5.8 & 4.0 & 0.17 & 8.9 & 21.2 & 1236 \\
\hline $6-35 \mathrm{Bm}$ & $\mathrm{O}$ & $1-1$ & Yadkin & 1985 & 5.2 & 4.2 & 0.17 & 8.7 & 21.5 & 1253 \\
\hline NI1001 & $\mathrm{O}$ & $1-2$ & Caldwell & 1974 & 5.5 & 3.3 & 0.13 & 9.8 & 23.8 & 1422 \\
\hline 4-38Bm & $\mathrm{O}$ & $1-2$ & Wilkes & 1985 & 6.7 & 5.0 & 0.21 & 11.1 & 39.0 & 1434 \\
\hline $7-29 B m$ & $\mathrm{O}$ & $1-2$ & Edgecombe & 1985 & 6.3 & 3.8 & 0.19 & 11.0 & 29.5 & 1517 \\
\hline NI1256 & $\mathrm{O}$ & $1-2$ & unknown & 1974 & 5.5 & 5.1 & 0.22 & 12.0 & 29.2 & 1570 \\
\hline NI934 & $\mathrm{O}$ & $1-2$ & Pitt & 1974 & 6.2 & 4.8 & 0.21 & 19.0 & 31.9 & 1727 \\
\hline NI1217 & $\mathrm{O}$ & $1-1$ & unknown & 1974 & 5.7 & 4.7 & 0.20 & 20.6 & 38.6 & 1773 \\
\hline NI1003 & $\mathrm{O}$ & $1-1$ & Yadkin & 1974 & 7.0 & 4.5 & 0.20 & 17.8 & 37.1 & 1785 \\
\hline $3-36 \mathrm{Bm}$ & $\mathrm{O}$ & $1-1$ & Wilkes & 1985 & 5.7 & 5.1 & 0.22 & 19.8 & 34.9 & 1804 \\
\hline $8-34 \mathrm{Bm}$ & $\mathrm{O}$ & $1-1$ & Wake & 1985 & 7.0 & 5.7 & 0.23 & 18.4 & 42.1 & 1880 \\
\hline $9-31 \mathrm{Bm}$ & $\mathrm{O}$ & $1-1$ & McDowell & 1985 & 5.7 & 5.9 & 0.25 & 20.3 & 46.1 & 1960 \\
\hline $2-16 \mathrm{Bm}$ & $\mathrm{O}$ & $1-2$ & Wilkes & 1985 & 6.5 & 4.8 & 0.20 & 21.1 & 47.4 & 2014 \\
\hline NI1011 & $\mathrm{O}$ & $1-1$ & Union & 1974 & 6.5 & 5.8 & 0.22 & 20.9 & 45.6 & 2034 \\
\hline NI1013 & $\mathrm{O}$ & $1-1$ & unknown & 1974 & 6.3 & 6.0 & 0.27 & 21.7 & 53.5 & 2142 \\
\hline $\operatorname{LSD}^{\mathrm{d}}(0.05)$ & & & & & 1.4 & 1.9 & 0.09 & 16.5 & 23.7 & 918 \\
\hline
\end{tabular}

a MAT = mating type allele (1-1 or $1-2)$.

${ }^{\mathrm{b}}$ County of origin in North Carolina.

c The lesion length data measured in the greenhouse experiment represent the mean of two repetitions, three replications each.

${ }^{\mathrm{d}} \mathrm{LSD}=$ Fisher's least significant difference $(P=0.05)$. 
or lesions (lesion assay) produced by tissue overwintered outdoors over the corresponding number of conidia or lesions, respectively, produced by tissue overwintered indoors under controlled conditions. These data were then subjected to ANOVA and regression analyses to determine significant differences among isolates in perennation and its possible relationship to aggressiveness in C. heterostrophus.

Leaf disc-sporulation assay. The 22 isolates of $C$. heterostrophus were also tested for their ability to colonize and sporulate on green or brown (senescent) maize leaf tissue. The experiment consisted of a factorial arrangement of the 22 isolates and two types of leaf discs arranged in a randomized complete block design with three replications. Isolates were grown for 5 days on $10 \mathrm{~g}$ PDA, and a $0.5-\mathrm{cm}$ plug transferred to the center of a $1.5 \%$ water agar petri plate. The plug was surrounded by 6 discs of either green or brown maize leaf tissue, $1 \mathrm{~cm}$ in diameter, and placed $2.5 \mathrm{~cm}$ from the PDA plug. Leaf discs were cut from either healthy green, field-grown maize leaves (green discs) or from dried, brown senescent leaves from field-grown maize (brown discs). All leaf discs were sterilized with gamma radiation $\left(\mathrm{Co}_{60}\right.$ source $)$ prior to placing on the agar medium. The resulting leaf disc assay plates were placed in a $28^{\circ} \mathrm{C}$ incubator for 7 days, after which the colonized leaf discs were removed, washed in $2 \mathrm{ml}$ water, and the conidial concentration of the resulting suspension determined with the aid of a hemacytometer. The experiment was repeated and data from both trials were combined and analyzed by ANOVA to determine differences in the ability of isolates to sporulate on green or senescent leaf tissue.

\section{RESULTS}

Isolate aggressiveness studies. The 22 isolates differed significantly in their level of aggressiveness in both the greenhouse and field trials (Table 1). Lesion length, lesion expansion rate, percent disease severity, and AUDPC were all highly correlated measures of isolate aggressiveness. The three race $\mathrm{T}$ isolates were significantly less aggressive than race $\mathrm{O}$ isolates in all tests. There were significant differences in aggressiveness among the race $\mathrm{O}$ isolates as well. Although the year $\times$ isolate interaction was highly significant $(P<0.01)$ in the combined analyses of the aggressiveness data, the correlation between each year's data was significant, and the effect of isolates in the combined ANOVA was significant or highly significant $(P<0.05$ to $P<0.01$, depending on the measure of aggressiveness) when tested with the isolate $\times$ year interaction term. Most of the isolate $\times$ year interactions appeared to be due to changes in the magnitude of differ- ences between isolates between years rather than changes in rank.

Perennation of isolates. Survival of the 22 isolates in leaf tissue on the soil surface during the winter of 1990 to 1991 was poor when measured by the leaf assay and by the sporulation assay (Table 2). There were significant $(P<0.05)$ differences in perennation among the isolates when measured by the lesion assay, but not with the sporulation assay. Perennation of the isolates on the soil surface during the winter of 1991 to 1992 was also low, but higher than the previous winter as measured by both the lesion and sporulation assays. Perennation was much greater in leaf tissue overwintered above the soil surface than at the soil surface. No lesion assay data were obtained from tissue overwintered in the winter of 1992 to 1993, as extreme drought damage to the plots made accurate counting of lesions impossible.

Sporulation on leaf discs. Sporulation of the 22 isolates was greater on green versus brown (senescent) leaf discs (Table 2). Significant differences in sporulation on leaf discs was observed among the isolates, and sporulation on both types of leaf disc was significantly positively correlated.

Correlations among traits. Pathogen aggressiveness measured by lesion length in both the field and greenhouse, lesion expansion rate, and percent SLB severity at the early dent stage was significantly

Table 2. Mean perennation (\% overwintering) of 22 isolates of Cochliobolus heterostrophus as measured by lesion number assays on a susceptible maize hybrid and sporulation assays of overwintered infected maize tissue, and sporulation on sterile senescent (brown) or green maize leaf discs

\begin{tabular}{|c|c|c|c|c|c|c|}
\hline \multirow[b]{3}{*}{ Isolate } & \multicolumn{4}{|c|}{ Perennation $(\%)^{\mathrm{a}}$} & & \\
\hline & \multicolumn{2}{|c|}{ Soil surface } & \multicolumn{2}{|c|}{ Above ground ${ }^{b}$} & \multicolumn{2}{|c|}{ Sporulation $^{\mathrm{c}}$} \\
\hline & Lesion assay $^{d}$ & Sporulation assay $^{b}$ & Lesion assay $^{\mathrm{e}}$ & Sporulation assay ${ }^{\mathrm{f}}$ & Brown & Green \\
\hline NI112 & 15.37 & 4.64 & 12.60 & 5.82 & 5.90 & 6.08 \\
\hline NI108 & 6.75 & 5.36 & 7.57 & 21.39 & 5.23 & 4.83 \\
\hline NI56 & 16.08 & 6.88 & 25.70 & 19.65 & 4.51 & 4.76 \\
\hline $1-1 \mathrm{Bm}$ & 3.29 & 1.76 & 12.63 & 28.64 & 4.92 & 5.45 \\
\hline NI109b & 9.84 & 2.42 & 20.59 & 12.56 & 5.40 & 5.62 \\
\hline $8-53 \mathrm{Bm}$ & 2.46 & 3.19 & 15.03 & 31.72 & 5.56 & 5.73 \\
\hline $9-39 \mathrm{Bm}$ & 7.51 & 3.16 & 49.20 & 68.41 & 5.10 & 5.32 \\
\hline $\mathrm{Hm} 28$ & 6.21 & 6.19 & 18.80 & 66.63 & 5.38 & 5.62 \\
\hline $6-35 \mathrm{Bm}$ & 4.14 & 4.11 & 30.90 & 13.67 & 5.70 & 5.88 \\
\hline NI1001 & 12.61 & 1.66 & 30.92 & 4.04 & 5.41 & 5.66 \\
\hline $4-38 \mathrm{Bm}$ & 2.95 & 0.70 & 18.30 & 6.68 & 5.55 & 5.58 \\
\hline 7-29Bm & 4.08 & 3.27 & 41.92 & 12.73 & 5.34 & 5.65 \\
\hline NI1256 & 5.05 & 0.67 & 15.48 & 7.67 & 5.36 & 5.73 \\
\hline NI934 & 6.83 & 1.21 & 10.79 & 5.81 & 5.42 & 5.55 \\
\hline NI1217 & 2.25 & 2.13 & 14.77 & 8.85 & 4.16 & 4.15 \\
\hline NI1003 & 11.71 & 6.98 & 36.32 & 15.53 & 5.70 & 5.49 \\
\hline 3-36Bm & 7.71 & 3.60 & 20.78 & 7.35 & 5.17 & 5.32 \\
\hline $8-34 \mathrm{Bm}$ & 5.56 & 5.12 & 23.67 & 15.01 & 5.83 & 5.79 \\
\hline $9-31 \mathrm{Bm}$ & 4.82 & 8.01 & 14.38 & 24.27 & 5.58 & 5.54 \\
\hline $2-16 \mathrm{Bm}$ & 6.48 & 1.43 & 25.37 & 10.97 & 5.66 & 5.73 \\
\hline NI1011 & 10.22 & 1.30 & 26.80 & 31.18 & 5.65 & 5.84 \\
\hline NI1013 & 2.03 & 1.99 & 24.93 & 3.07 & 5.26 & 5.30 \\
\hline $\operatorname{LSD}(0.05)^{\mathrm{g}}$ & 7.21 & 4.65 & ns & ns & 0.40 & 0.40 \\
\hline
\end{tabular}

${ }^{\mathrm{a}}$ Perennation $=$ (lesions or spores produced by infected leaf tissue overwintered outdoors at Raleigh, North Carolina/lesions or spores produced by infected leaf tissue stored indoors under favorable conditions) $\times 100$.

b Mean over 3 years.

${ }^{\mathrm{c}} \log _{10} \#$ spores/6 discs.

${ }^{\mathrm{d}}$ Mean over 2 years.

${ }^{\mathrm{e}}$ Mean of 1 year (1992 to 1993) only.

${ }^{\mathrm{f}}$ Mean of 2 years.

${ }^{\mathrm{g}} \mathrm{LSD}=$ Fisher's least significant difference $(P=0.05)$; ns $=$ not significant. 
negatively correlated with perennation as measured by the lesion assay of tissue overwintered on the soil surface (Table 3), but not with perennation measured by the sporulation assay. All measures of aggressiveness were negatively correlated with percent perennation on the soil surface even if they were not statistically significant. When only race $\mathrm{O}$ isolates were considered, only lesion expansion rate was significantly negatively correlated with percent overwintering as measured by the lesion assay. Percent perennation above ground as measured by the lesion assay was significantly positively correlated with greenhouse lesion length only. Aggressiveness of all isolates was not significantly correlated with sporulation on either green or brown maize leaf discs but, when only race $\mathrm{O}$ isolates were considered, sporulation on brown leaf discs was significantly positively correlated with aggressiveness as measured by lesion length in both the field and greenhouse and lesion expansion rates. There was no significant correlation between perennation measured by the lesion assay and the sporulation assay (data not shown).

\section{DISCUSSION}

Evidence is presented here that the ability of isolates of C. heterostrophus to perennate was often significantly negatively correlated with their aggressiveness (as measured by the lesion assay of tissue overwintered on the soil surface). This supports the hypothesis that competence in perennation or overwintering may be a selective force in the $C$. heterostrophus population. It is not clear that the strength of this correlation is sufficient to explain the persistence of less-aggressive strains in nature. The race $\mathrm{T}$ isolates of $C$. heterostrophus appeared to overwinter better than the race $\mathrm{O}$ isolates in this study. Several studies have shown that race $\mathrm{T}$ is less fit than $\mathrm{O}$ on normal cytoplasm maize, and its frequency in the $C$. heterostrophus population declined to near zero quite rapidly once cms-T maize hybrids were no longer grown in the United States $(9,11,12,22,23)$. Thus the apparent increased ability of race $\mathrm{T}$ isolates to perennate observed in the current study was not apparently sufficient to compensate for its reduced fitness on normal cytoplasm maize during the parasitic phase of its life cycle.

Although the ability to perennate may be a selective force in the $C$. heterostrophus population, these data suggest that perennation ability may not be highly heritable, at least as measured by the means reported here. Whether by the lesion assay or the more direct sporulation assay, the ability to detect even relatively large differences in the ability to perennate among isolates was difficult. Perennation was apparently not related to the ability of isolates to grow saprophytically and sporulate on senescent host tissue. The very low survival rate on leaf tissue that had overwintered on the soil surface indicates that $C$. heterostrophus may not be an efficient saprophyte. This observation is consistent with overwintering studies of race $\mathrm{T}$ conducted following the 1970 SLB epidemic $(5,6,18,20,28,29)$. Despite its limited ability to persist in host residues, there was a significant relationship between aggressiveness among race $\mathrm{O}$ isolates and their ability to sporulate on senescent host tissues. A similar relationship between parasitic fitness and sporulation of races of $C$. carbonum also has been reported (33).

Taken together, these data add little support to the hypothesis that less-aggressive isolates of $C$. heterostrophus are maintained in the population by selection oper- ating during perennation or saprophytic phases of their life cycle. If such selection is operating, its effects are probably slight, given the low heritability of aggressiveness among race $\mathrm{O}$ isolates (10) and the apparent low heritability of perennation ability as observed in these studies. Other possible selection forces that may account for maintaining polymorphism for aggressiveness in $C$. heterostrophus and that invite further exploration include some form of density or frequency dependent selection, or host genotype.

\section{LITERATURE CITED}

1. Burnette, D. C. and White, D. G. 1985. Inheritance of resistance to Bipolaris maydis race $\mathrm{O}$ in crosses derived from nine resistant inbred lines of maize. Phytopathology 75:1195-1200.

2. Byrnes, K. J., Pataky, J. K., and White, D. G. 1989. Relationships between yield of three maize hybrids and severity of southern leaf blight caused by race $\mathrm{O}$ of Bipolaris maydis. Plant Dis. 73:834-840.

3. Craig, J., and Fajemisin, J. M. 1969. Inheritance of chlorotic lesion resistance to Helminthosporium maydis in maize. Plant Dis. Rep. 53:742-743.

4. Fisher, D. A., Hooker, A. L., Lim, S. M., and Smith, D. R. 1976. Leaf infection and yield loss caused by four Helminthosporium leaf diseases of corn. Phytopathology 66:942-944.

5. Futrell, M. C., and Scott, G. E. 1971. Overwintering and early season development of Helminthosporium maydis in Mississippi. Plant Dis. Rep. 55:954-956.

6. Gudauskas, R. T., Teem, D. H., To, W., and Whatley, T. L. 1971. Overwintering of Helminthosporium maydis in Alabama. Plant Dis. Rep. 55:947-948.

7. Holley, R. N., and Goodman, M. M. 1989 New sources of resistance to southern corn leaf blight from tropical maize derivatives. Plant Dis. 73:562-564.

8. Hooker, A. L., Smith, D. R., Lim, S. M., and Musson, M. D. 1970. Physiological races of Helminthosporium maydis and disease resistance. Plant Dis. Rep. 54:1109-1110.

9. Klittich, C. J. R., and Bronson, C. R. 1986.

Table 3. Correlation coefficients between measures of perennation and sporulation on senescent and green maize leaf discs, and aggressiveness of 22 isolates of Cochliobolus heterostrophus

\begin{tabular}{|c|c|c|c|c|c|c|}
\hline \multirow[b]{2}{*}{$\%$ Perennation } & \multicolumn{2}{|c|}{ Lesion length (mm) } & \multirow[b]{2}{*}{$\operatorname{LER}(\mathbf{m m} / \text { day })^{b}$} & \multicolumn{2}{|c|}{$\% \mathbf{S L B}^{\mathbf{a}}$} & \multirow[b]{2}{*}{ AUDPC } \\
\hline & Greenhouse & Field & & Mid-silk & Early dent & \\
\hline \multicolumn{7}{|l|}{$\begin{array}{l}\text { Soil surface } \\
\text { sil }\end{array}$} \\
\hline lesion assay & $\begin{array}{l}-0.47 * \mathrm{~d} \\
(-0.24 \mathrm{~ns})^{\mathrm{e}}\end{array}$ & $\begin{array}{c}-0.53 * * \\
(-0.41+)\end{array}$ & $\begin{array}{c}-0.64 * * * \\
(-0.57 * *)\end{array}$ & $\begin{array}{c}-0.30 \mathrm{~ns} \\
(-0.13 \mathrm{~ns})\end{array}$ & $\begin{array}{l}-0.42 * \\
(-0.28 \mathrm{~ns})\end{array}$ & $\begin{array}{c}-0.32 \mathrm{~ns} \\
(-0.15 \mathrm{~ns})\end{array}$ \\
\hline sporulation assay & $\begin{array}{l}-0.11 \mathrm{~ns} \\
(-0.05 \mathrm{~ns})\end{array}$ & $\begin{array}{c}-0.22 \mathrm{~ns} \\
(-0.13 \mathrm{~ns})\end{array}$ & $\begin{array}{c}-0.23 \mathrm{~ns} \\
(-0.20 \mathrm{~ns})\end{array}$ & $\begin{array}{c}-0.16 \mathrm{~ns} \\
(-0.10 \mathrm{~ns})\end{array}$ & $\begin{array}{c}-0.20 \mathrm{~ns} \\
(-0.14 \mathrm{~ns})\end{array}$ & $\begin{array}{c}-0.18 \mathrm{~ns} \\
(-0.12 \mathrm{~ns})\end{array}$ \\
\hline \multicolumn{7}{|l|}{ Above ground } \\
\hline lesion assay & $\begin{array}{l}0.46^{*} \\
(0.31 \mathrm{~ns})\end{array}$ & $\begin{array}{c}0.18 \mathrm{~ns} \\
(-0.14 \mathrm{~ns})\end{array}$ & $\begin{array}{c}0.21 \mathrm{~ns} \\
(-0.07 \mathrm{~ns})\end{array}$ & $\begin{array}{c}0.25 \mathrm{~ns} \\
(0.06 \mathrm{~ns})\end{array}$ & $\begin{array}{c}0.18 \mathrm{~ns} \\
(-0.04 \mathrm{~ns})\end{array}$ & $\begin{array}{c}0.16 \mathrm{~ns} \\
(-0.07 \mathrm{~ns})\end{array}$ \\
\hline sporulation assay & $\begin{array}{c}0.19 \mathrm{~ns} \\
(0.12 \mathrm{~ns})\end{array}$ & $\begin{array}{l}-0.01 \mathrm{~ns} \\
(-0.16 \mathrm{~ns})\end{array}$ & $\begin{array}{c}0.04 \mathrm{~ns} \\
(-0.11 \mathrm{~ns})\end{array}$ & $\begin{array}{c}-0.09 \mathrm{~ns} \\
(-0.21 \mathrm{~ns})\end{array}$ & $\begin{array}{l}-0.20 \mathrm{~ns} \\
(-0.36 \mathrm{~ns})\end{array}$ & $\begin{array}{r}-0.27 \mathrm{~ns} \\
(-0.42+)\end{array}$ \\
\hline \multicolumn{7}{|c|}{ Sporulation (log spore \#) } \\
\hline Brown leaf discs & $\begin{array}{c}0.11 \mathrm{~ns} \\
\left(0.55^{*}\right)\end{array}$ & $\begin{array}{c}0.17 \mathrm{~ns} \\
\left(0.45^{*}\right)\end{array}$ & $\begin{array}{c}0.13 \mathrm{~ns} \\
(0.42+)\end{array}$ & $\begin{array}{c}0.07 \mathrm{~ns} \\
(0.21 \mathrm{~ns})\end{array}$ & $\begin{array}{c}0.19 \mathrm{~ns} \\
(0.38 \mathrm{~ns})\end{array}$ & $\begin{array}{c}0.18 \mathrm{~ns} \\
(0.34 \mathrm{~ns})\end{array}$ \\
\hline Green leaf discs & $\begin{array}{l}0.07 \mathrm{~ns} \\
(0.34 \mathrm{~ns})\end{array}$ & $\begin{array}{c}0.11 \mathrm{~ns} \\
(0.24 \mathrm{~ns})\end{array}$ & $\begin{array}{c}0.08 \mathrm{~ns} \\
(0.24 \mathrm{~ns})\end{array}$ & $\begin{array}{l}-0.05 \mathrm{~ns} \\
(-0.05 \mathrm{~ns})\end{array}$ & $\begin{array}{c}0.06 \mathrm{~ns} \\
(0.11 \mathrm{~ns})\end{array}$ & $\begin{array}{c}0.06 \mathrm{~ns} \\
(0.10 \mathrm{~ns})\end{array}$ \\
\hline
\end{tabular}

a Percent southern leaf blight (SLB) disease severity at the mid-silk and early dent stages of host development.

${ }^{\mathrm{b}}$ LER $=$ lesion expansion rate.

$\mathrm{c}$ AUDPC $=$ area under disease progress curve.

$\mathrm{d}+, *, * *$, and $* * *$ indicate correlations coefficient not significantly different or significantly different from zero at the $0.10,0.05,0.01$, and 0.001 levels of probability, respectively. ns $=$ not significant.

${ }^{\mathrm{e}}$ Coefficients in parentheses are those calculated using only data from isolates of race $\mathrm{O}$ of $C$. heterostrophus. 
Reduced fitness associated with TOX1 of Cochliobolus heterostrophus. Phytopathology 76:1294-1298.

10. Kolmer, J. A., and Leonard, K. J. 1986. Genetic selection and adaptation of Cochliobolus heterostrophus to corn hosts with partial resistance. Phytopathology 76:774-777.

11. Leonard, K. J. 1977. Races of Bipolaris maydis in the southeastern US from 1974-1976. Plant Dis. Rep. 61:914-915.

12. Leonard, K. J. 1977. Virulence, temperature optima, and competitive abilities of isolines of races $\mathrm{T}$ and $\mathrm{O}$ of Bipolaris maydis. Phytopathology 67:1273-1279.

13. Leonard, K. J., Thakur, R. P., and Leath, S. 1988. Incidence of Bipolaris and Exserohilum species in corn leaves in North Carolina. Plant Dis. 72:1034-1038.

14. Levings, C. S. III 1990. The Texas cytoplasm of maize: Cytoplasmic male sterility and disease susceptibility. Science 250:942-947.

15. Levings, C. S. III, and Siedow, J. N. 1992. Molecular basis of disease susceptibility in the Texas cytoplasm of maize. Plant Mol. Biol. 19:135-147.

16. Lim, S. M. 1975. Heterotic effects of resistance in maize to Helminthosporium maydis race O. Phytopathology 65:1117-1120.

17. Lim, S. M., and Hooker, A. L. 1976. Estimates of combining ability for resistance to Helminthosporium maydis race $\mathrm{O}$ in a maize population. Maydica 21:121-128.
18. Littrell, R. H., and Sumner, D. R. 1971. Overwintering of Helminthosporium maydis in Georgia. Plant Dis. Rep. 55:951-953.

19. Pate, J. R., and Harvey, P. H. 1954. Studies on the inheritance of resistance in corn to Helminthosporium maydis leaf spot. Agron. J. 46:442-445.

20. Schenck, N. C. 1971. Overwintering of Helminthosporium maydis in Florida. Plant Dis. Rep. 55:949-951.

21. Shurtleff, M. C., ed. 1980. Compendium of Corn Diseases, 2nd ed. American Phytopathological Society, St. Paul, MN.

22. Smith, D. R. 1977. Monitoring corn pathogens. Pages 106-121 in: Proc. Annu. Corn Sorghum Res. Conf. 32. H. D. Loden and D. Wilkinson, eds. ASTA, Washington, DC.

23. Smith, D. R. 1984. Monitoring corn pathogens nationally. Pages 101-136 in: Proc. 20th Annu. Illinois Corn Breeders School. D. E. Alexander, ed. University of Illinois, Champaign.

24. Smith, D. R., and Hooker, A. L. 1973. Monogenic chlorotic-lesion resistance in corn to Helminthosporium maydis. Crop Sci. 13:330331.

25. Smith, D. R., Hooker, A. L., and Lim, S. M. 1970. Physiologic races of Helminthosporium maydis. Plant Dis. Rep. 54:819-822.

26. Smith, D. R., and White, D. G. 1988. Diseases of corn. In: Corn and Corn Improvement, G. F. Sprague and J. W. Dudley, eds. Agronomy
18:687-766.

27. Thompson, D. L., and Bergquist, R. R. 1984 Inheritance of mature plant resistance to Helminthosporium maydis race $\mathrm{O}$ in maize. Crop Sci. 24:807-811

28. Thompson, D. L., and Herbert, T. T. 1971. Winter survival of Helminthosporium maydis in North Carolina. Plant Dis. Rep. 55:956-959.

29. Ullstrup, A. J. 1971. Overwintering of race T of Helminthosporium maydis in midwestern United States. Plant Dis. Rep. 55:563-565.

30. Ullstrup, A. J. 1972, The impacts of the southern corn leaf blight epidemics of 197071. Annu. Rev. Phytopathol. 10:37-50.

31. Ullstrup, A. J., and Miles S. R. 1957. The effects of some leaf blights of corn on grain yield. Phytopathology 47:331-336.

32. Wei, J., Lui, K., Chen, J., Luo, P., and LeeStadelmann, O. Y. 1988. Pathological and physiological identification of race $\mathrm{C}$ of $\mathrm{Bi}$ polaris maydis in China. Phytopathology 78:550-554.

33. Welz, H. G., Leath, S., and Leonard, K. J. 1993. Sporulation of races 0,2, and 3 of Cochliobolus carbonum on synthetic medium and sterilized corn leaves. Plant Dis. 77:11531157.

34. Wilcoxson, R. D., Atif, A. H., and Skovmand, B. 1974. Slow rusting of wheat varieties in the field correlated with stem rust severity on detached leaves in the greenhouse. Plant Dis. Rep. 58:1085-1087. 